\title{
Differential expression of thyroid hormone receptor isoforms is strikingly related to cardiac and skeletal muscle phenotype during postnatal development
}

\section{P White and M J Dauncey}

The Babraham Institute, Cambridge CB2 4AT, UK

(Requests for offprints should be addressed to M J Dauncey; E-mail: joy.dauncey@bbsrc.ac.uk)

\begin{abstract}
The genomic actions of thyroid hormones (THs) are mediated by receptors (TRs) that are encoded by two protooncogenes, c-erbA- $\alpha$ and c-erbA- $\beta$. The precise functions of the TR isoforms are unclear and this study focuses on the potential roles of the $\mathrm{TR} \alpha$ and TR $\beta$ isoforms in mammalian striated muscles postnatally. The porcine TR $\alpha 1, T R \alpha 2$ and TR $\beta 1$ cDNAs were first cloned, sequenced and characterised by Northern blotting. A quantitative analysis of TR isoform expression was then undertaken, using RNase protection analysis with novel riboprobes designed to detect relative expression levels of TR $\alpha 1, T R \alpha 2, T R \beta 1$ and TR $\beta 2$, in functionally distinct muscles from 7 -week-old pigs kept under controlled conditions of nutrition and thermal environment. We found a striking musclespecific pattern of $\mathrm{TR} \alpha$ isoform distribution: in
\end{abstract}

heart the mRNA level of TR 22 (non-TH binding) was markedly greater $(P<0 \cdot 01)$ than that of TR 1 (TH binding); in longissimus dorsi the opposite pattern of expression occurred (TR $\alpha 1>\mathrm{TR} \alpha 2$, $P<0.001)$; in soleus, diaphragm and rhomboideus there were no differences between the two isoforms. The overall abundance of TR $\beta$ was very much lower than that of TR $\alpha$, and TR $\beta 1$ was expressed at a higher level than TR $\beta 2$ in all muscles. Together with recent data from TR gene inactivation studies and the established role of $\mathrm{TH}$ in determining myosin heavy chain isoform expression and muscle phenotype, these results suggest a role for differential expression of TR isoforms in acquisition and maintenance of optimal cardiac and skeletal muscle function.

Fournal of Molecular Endocrinology (1999) 23, 241-254

\section{INTRODUCTION}

Thyroid hormones (THs: L-tri-iodothyronine, $\mathrm{T}_{3}$; L-tetra-iodothyronine, thyroxine, $\mathrm{T}_{4}$ ) play central roles in the control of growth, development and metabolism (Oppenheimer et al. 1987, Dauncey 1990, Chin \& Yen 1997) and they are essential for normal development and function of striated muscle (Muscat et al. 1995). Coincident with a perinatal increase in circulating $\mathrm{TH}$ levels, embryonic and neonatal myosin heavy chain $(\mathrm{MyHC})$ isoforms are repressed and adult $\mathrm{MyHC}$ isoforms are accumulated, and there are also marked muscle-specific changes in cellular metabolism and mitochondrial biogenesis (d'Albis \& Butler-Browne 1993, Herpin et al. 1996). Postnatally, THs continue to influence muscle phenotype, changing transcription levels of myogenic regulatory factors, altering membranebound ATPases and metabolic properties, and inducing switching from type I slow to type II fast
MyHC, with the extent of these changes being dependent on muscle type (Izumo et al. 1986, Dauncey \& Harrison 1996, Harrison et al. 1996b, 1997).

THs act at many sites within the cell (Davis \& Davis 1997), and their major influence is at the genomic level via a group of nuclear receptors (TRs) which regulate the expression of numerous target genes (Green \& Chambon 1986, Munoz \& Bernal 1997). The TR $\alpha$ gene (c-erbA- $\alpha$ ) produces an RNA transcript that is alternatively spliced to produce the carboxyl terminal variants TR $\alpha 1, T R \alpha 2$ and, in mice, TR $\alpha 3$, while the $\operatorname{TR} \beta$ gene $(\mathrm{c}-\operatorname{erb} \mathrm{A}-\beta)$ produces two amino terminal variants, TR $\beta 1$ and TR $\beta 2$ (Lazar 1993). The TR $\alpha 1, T R \beta 1$ and TR $\beta 2$ isoforms can bind $\mathrm{TH}$ and transactivate $\mathrm{TH}$ response elements (TREs) on target genes. However, TR $\alpha 2$ cannot bind TH because of structural changes in the ligand binding domain (LBD). Although this results in reduced DNA binding affinity, TR $\alpha 2$ is thought to compete for TREs and 
to act as a dominant negative regulator of $\mathrm{TH}$ activity (Yen \& Chin 1994, Yang et al. 1996).

Nuclear TH binding studies in porcine tissues indicate that perinatal TR ontogeny is different in skeletal muscle compared with liver (Duchamp et al. 1994), and that energy status plays a key role in regulating muscle TRs postnatally (Morovat \& Dauncey 1995). However, the precise functions of the individual TR isoforms are unclear. Gene inactivations of TR $\alpha 1, \operatorname{TR} \alpha 1 / \alpha 2$ and TR $\beta$ in mice suggest that differential expression of TR isoforms in developing and adult tissues reflects differences in function (Hsu \& Brent 1998). Despite the profound influences of THs on different muscle types, there is, however, virtually no information on TR isoform expression in functionally distinct muscles.

The aims of the present study were to clone and characterise the cDNAs encoding the porcine TR isoforms, and to determine the relative expression of these isoforms in functionally distinct skeletal and cardiac muscles during postnatal development. The focus was on porcine TRs because the young pig makes a particularly good model for the human infant in relation to many developmental, metabolic, endocrine and physiological characteristics. We describe a novel method for quantifying TR isoform mRNAs, using riboprobes designed to detect both $\mathrm{TR} \alpha$ isoforms and both TR $\beta$ isoforms simultaneously. Our findings highlight distinct musclespecific differential expression patterns of the TR isoforms and suggest key roles for these isoforms in the acquisition and maintenance of optimal muscle function postnatally.

\section{MATERIALS AND METHODS}

\section{Animals and tissues}

Previous studies have demonstrated that energy status profoundly affects nuclear TH binding capacity (Morovat \& Dauncey 1995), and that food intake influences TR isoform expression (Bakker et al. 1998). All tissues were therefore obtained from animals kept under carefully controlled conditions of food intake and thermal environment. Five male pigs (Sus scrofa) of the Large White breed were obtained at 3 weeks of age and housed at a temperature close to thermal neutrality $\left(26^{\circ} \mathrm{C}\right)$. For the next 4 weeks, the animals were provided with a controlled amount of food that enabled optimal growth. Because several hormonal and metabolic parameters are influenced by the time of the last meal (Dauncey et al. 1994, Morovat \& Dauncey 1998), tissue sampling was carried out $20 \mathrm{~h}$ after feeding. At 7 weeks, the animals were sedated and then killed with sodium pentobarbitone as described previously (Harrison et al. 1996a). The following tissues were dissected rapidly, divided into $1-5 \mathrm{~g}$ portions, frozen in liquid nitrogen and stored at $-70{ }^{\circ} \mathrm{C}$ : cardiac ventricular muscle, soleus, diaphragm, rhomboideus, longissimus dorsi, liver, thyroid gland and cerebrum.

\section{RNA isolation}

Total RNA was extracted from $0.5 \mathrm{~g}$ portions of tissue using a method based on the guanidine thiocyanate method of Chomczynski \& Sacchi (1987). The final RNA pellet was dissolved in $0 \cdot 3 \mathrm{M}$ sodium acetate, $\mathrm{pH} 5 \cdot 2$ and quantified by duplicate absorbance readings at $260 \mathrm{~nm}$. A constant relation between $\mathrm{A}_{260}$ and poly(A)+ content was found for RNA from all tissues. RNA samples were stored in ethanol at $-70{ }^{\circ} \mathrm{C}$.

\section{Cloning}

First-strand cDNA was synthesised from $1 \mu \mathrm{g}$ heart total RNA using an oligo(dT) primer in combination with a genetically engineered $\mathrm{RNase} \mathrm{H}^{-}$ Moloney murine leukaemia virus reverse transcriptase (SuperScript II RNase $\mathrm{H}^{-}$MMLV-RT, Gibco BRL, Paisley, Strathclyde, UK). This enzyme is reported to perform reverse transcription more faithfully than other RT enzymes while not degrading RNA, thus giving higher yields of cDNA and more full-length product (Kotewicz et al. 1988). Oligonucleotide primer pairs were designed according to the published human TRa1 (Laudet et al. 1991), TRa2 (Nakai et al. 1988) and TRß1 (Weinberger et al. 1986) sequences (Accession Numbers X55005, J03239 and X04707 for $\alpha 1, \alpha 2$ and $\beta 1$ respectively). The polymerase chain reaction (PCR) was carried out using the heart cDNA as a template to generate both $\operatorname{TR} \alpha$ and $\operatorname{TR} \beta$ DNA fragments as indicated in Fig. 1. To ensure that the PCR amplification produced DNA with a sequence true to that of the template, a high fidelity DNA polymerase system was used (Expand High Fidelity PCR System, Boehringer Mannheim, Lewes, East Sussex, UK). The inherent $3^{\prime}-5^{\prime}$ exonuclease proof-reading activity of the Pwo DNA polymerase contained in this system resulted in high fidelity DNA synthesis (Barnes 1994). Amplified DNA fragments were purified and cloned into pGEM-T Easy plasmid vector (Promega, Southampton, Hants, UK). These plasmids were then used as templates for automated fluorescent sequencing using an Applied Biosystem Prism 377 DNA sequencer. 

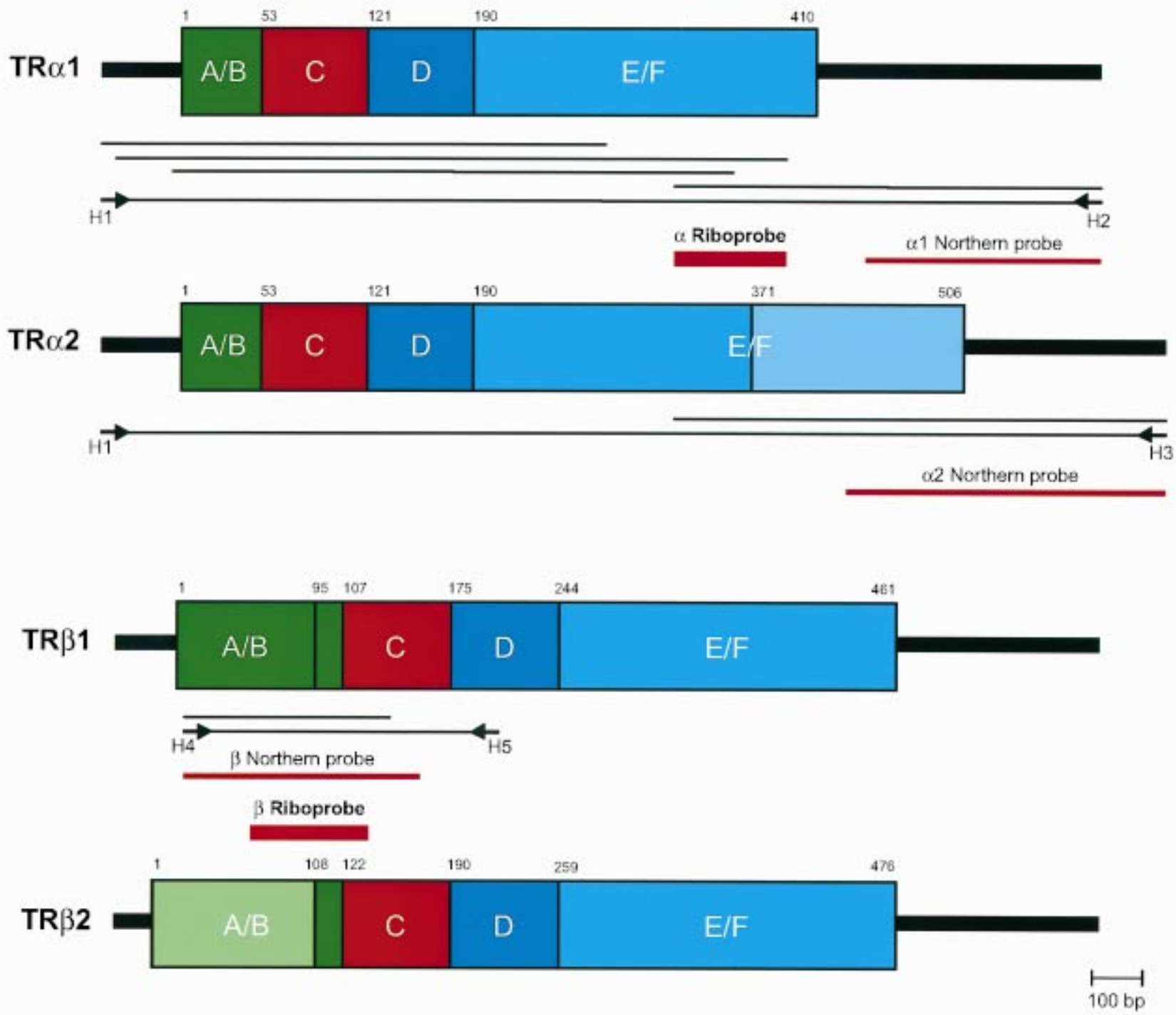

FIGURE 1. Schematic representation of thyroid hormone receptor (TR) isoform structures, based on deduced amino acid sequences from cloned porcine cDNAs for TR $\alpha$ (Fig. 2) and those of human for TR $\beta$. Colours represent the functional domains common to all nuclear hormone receptors: green, amino terminal transactivation domain $(\mathrm{A} / \mathrm{B})$; red, DNA binding domain (C); blue, ligand binding domain, consisting of hinge region (D), and carboxy ligand binding and dimerisation domains (E/F). Numbering of amino acid residues is indicated above the domains. The two $\mathrm{TR} \alpha$ variants are homologous from the $5^{\prime}$ end to amino acid 370; after this point the sequences diverge, as represented by the light blue of the TR $\alpha 2$ variant. The two TR $\beta$ isoforms differ in their N-terminal section, as indicated by the lighter green of the TR $\beta 2$ variant. Coding region is flanked by two thick black lines representing $5^{\prime}$ and $3^{\prime}$ untranslated regions. Thin black lines underneath each structure show positions of overlapping cDNA clones used to sequence the variants. Arrows denote location of primers designed according to the human TR $\alpha$ (H1, H2, $\mathrm{H} 3)$ and TR $\beta(\mathrm{H} 4, \mathrm{H} 5)$ sequences used in PCR amplification of the porcine TR cDNAs. Red lines denote probe sequences: thin lines represent the three cDNA fragments used in Northern blot analyses; thick lines represent riboprobes used in RNase protection analyses. The TR $\alpha$ riboprobe was 100\% homologous to TR $\alpha 1$ and $70 \%$ homologous to TR $\alpha 2$, giving 218 and 153 bp protection products respectively. The TR $\beta$ riboprobe was $100 \%$ homologous to TR $\beta 1$ and $67 \%$ homologous to TR $\beta 2$, giving 230 and 154 bp protection products respectively. 
Initially, several overlapping fragments were cloned (Fig. 1), ranging in size from 500 to $1500 \mathrm{bp}$. The sequences of these smaller fragments were combined to give complete cDNA sequences for TR $\alpha 1$ and TR $\alpha 2$, and a partial cDNA sequence for TR $\beta 1$. To verify the sequence data, the complete TR $\alpha 1$ and TR $\alpha 2$ cDNAs were cloned as two single PCR products. This was achieved using primers designed within the $5^{\prime}$ and $3^{\prime}$ untranslated regions (UTR) of the TR $\alpha 1$ and TR $\alpha 2$ mRNAs. For TR $\alpha 1$, the 5' primer, H1 (5'-TGTGAAAGGCCAAGTG CTG-3'), comprised nucleotides -155 to -137 of the human TR $\alpha 1$ sequence. The 3' TR 1 1-specific primer, H2 (5'-GCCTGGTTTCCAAAGTGCA$\left.3^{\prime}\right)$, comprised nucleotides 1755 to 1773 of the human TR 1 sequence. For TR 2 , primer H1 was used with the $3^{\prime}$ TR 2 2-specific primer, H3 (5'-ACAGACTCATGCCCGACT-3'), complementary to nucleotides 1842 to 1860 . The largest fragment of the porcine TR $\beta 1 \mathrm{cDNA}$ was produced with the TR $\beta 1$-specific $5^{\prime}$ primer, H4 (5'-AGC TTGGGACAAACCGAAG-3'), which comprised nucleotides 21 to 39 of the human TR $\beta 1$ sequence, and the $3^{\prime}$ TR $\beta$ primer, H5 (5'-CTGTGGGCTC TGGCTTGTG-3'), complementary to nucleotides 613 to 631 of the human TR $\beta 1$ sequence.

To exclude completely the possibility that either the DNA polymerase or the sequencing run had generated variations in nucleotide sequence, at least two clones were generated from independently reverse transcribed cDNA samples from heart RNA extracted from two different animals. Sequencing was carried out in both the sense and anti-sense directions for every DNA fragment cloned.

\section{Northern blot analysis}

Northern blot analysis was used to characterise the mRNAs encoding the porcine $\mathrm{TR} \alpha$ isoforms. Samples of total RNA ( $20 \mu \mathrm{g})$ extracted from each tissue were denatured at $85^{\circ} \mathrm{C}$ for $3 \mathrm{~min}$ in buffer containing $2 \cdot 2 \mathrm{M}$ formaldehyde, $50 \%$ formamide, $33 \mu \mathrm{g} / \mathrm{ml}$ ethidium bromide, and $1 \times$ MOPS buffer (20 mM 3-[N-morpholino]propanesulphonic acid, $5 \mathrm{mM}$ sodium acetate, $1 \mathrm{mM}$ EDTA). The RNA transcripts were separated by electrophoresis in a denaturing formaldehyde gel $(0.22 \mathrm{M}$ formaldehyde, $0.9 \%$ agarose) in $1 \times$ MOPS buffer. Ethidium bromide staining confirmed equal loading of RNA per lane and all samples were run against an RNA ladder for size comparison (Gibco BRL). The separated RNA was transferred to a nylon membrane (Hybond-N, Amersham International, Amersham, Bucks, UK) using a pressure blotter (PosiBlot, Stratagene, Cambridge, Cambs, $\mathrm{UK})$.
Three double-stranded DNA probes (Fig. 1) were generated using PCR. The first, a $458 \mathrm{bp}$ TR 11 -specific probe, corresponded to nucleotides 1332 to 1773 of the porcine TR $\alpha 1$ coding sequence (cds). The second was a $623 \mathrm{bp}$ TR $\alpha 2$-specific probe, corresponding to nucleotides 1294 to 1860 of the porcine TR $\alpha 2 \mathrm{cds}$. The third was a $458 \mathrm{bp}$ TR $\beta 1$ and $\beta 2$ common probe, corresponding to nucleotides 21 to 478 of the porcine TR $\beta 1$ cds. Each of these DNA fragments was labelled with $\left[\alpha-{ }^{32} \mathrm{P}\right] \mathrm{dCTP}$ using a random priming labelling kit (Rediprime DNA labelling system, Amersham International). Blots were pre-hybridised at $65^{\circ} \mathrm{C}$ in commercially available hybridisation buffer (Rapidhyb buffer, Amersham International) for $1 \mathrm{~h}$. The pre-hybridisation buffer was then replaced with fresh buffer containing $\sim 2 \mathrm{ng} / \mathrm{ml}$ of the appropriate radiolabelled DNA probe, and left to hybridise for $4 \mathrm{~h}$ at $65^{\circ} \mathrm{C}$. Blots were washed in $0 \cdot 1 \times \mathrm{SSC}$ $(15 \mathrm{mM}$ sodium chloride, $1.5 \mathrm{mM}$ sodium citrate, $\mathrm{pH} 7 \cdot 0$ ) and $0 \cdot 1 \% \mathrm{SDS}$ at $65^{\circ} \mathrm{C}$ for $2 \times 10 \mathrm{~min}$, before autoradiography.

\section{Construction of TR riboprobes and RNase protection analysis}

RNase protection analysis was used in detailed expression studies of TR isoform abundance in functionally distinct muscles. When optimised, this is an extremely sensitive method for the detection and quantification of specific RNAs in a complex mixture of total cellular RNA, and the reaction can be 10 - to $100+$-fold more sensitive than Northern blotting (Melton et al. 1984). Using the newly established porcine TR $\alpha$ and TR $\beta$ cDNA sequences, two probes were designed for detection of expression levels of all four TR isoforms (Fig. 1). The TR $\alpha$ probe was generated by PCR using oligonucleotide primers as follows: the $5^{\prime}$ primer, 5'-AGGCTGTGCTGCTAATGTCA-3', comprised the sequence between nucleotides 958 and 977; the 3' primer, 5'-GCACTCGACTTTCAT GTGGA-3', was complementary to nucleotides 1156 to 1175 . PCR was carried out using the complete porcine TR $\alpha 1 \mathrm{cDNA}$ as a template. The resulting $218 \mathrm{bp}$ DNA fragment was blunt-end cloned into an EcoRV linearised plasmid (pBluescript KS (+/-), Stratagene). DNA sequencing revealed that the DNA fragment had been cloned in the sense direction. For TR $\beta$, the $5^{\prime}$ primer, 5'-CCATCTGGACCACGACGATG-3', comprised the sequence between nucleotides 189 and 208; the 3' primer, 5'-AGGAATAGGATGGA TGGAG-3', was complementary to nucleotides 400 to 418. PCR was carried out using the cloned fragment of the porcine TR $\beta 1$ cDNA as a template. 
The resulting $230 \mathrm{bp}$ DNA was similarly cloned into pBluescript $\mathrm{KS}(+/-)$ and DNA sequencing revealed that the DNA fragment had been cloned in the antisense direction.

Antisense riboprobes were generated by linearising the plasmid by digestion with HindIII or EcoRI and then transcribing with $\mathrm{T} 7$ or T3 RNA polymerase, for $\mathrm{TR} \alpha$ and $\mathrm{TR} \beta$ respectively, in the presence of $\left[\alpha^{32} \mathrm{P}\right] \mathrm{UTP}$ (Amersham International). The TR $\alpha$ riboprobe had a full-length transcript of $295 \mathrm{bp}$, of which $218 \mathrm{bp}$ hybridised fully to TR $\alpha 1$, corresponding to nucleotides 958 to 1175 . Since this probe spanned the carboxyl terminal region, where TR $\alpha 1$ and TR $\alpha 2$ have differences in the LBD, a second protection product of $153 \mathrm{bp}$ was formed, corresponding to nucleotides 958 to 1110 of TR $\alpha 2$. Similarly, the TR $\beta$ riboprobe had a full-length transcript of $293 \mathrm{bp}$, of which $230 \mathrm{bp}$ hybridised fully to TR $\beta 1$, corresponding to nucleotides 189 to 418. Since this probe spanned the amino terminal region, where TR $\beta 1$ and TR $\beta 2$ have differences in the amino terminal (A/B) domain, a second protection product of $154 \mathrm{bp}$ was formed, corresponding to nucleotides 265 to 418 of TR $\beta 2$. Thus, these single probes allowed accurate measurement of the expression levels of both TR $\alpha$ isoforms and both TR $\beta$ isoforms within a single assay.

Assays were carried out on $50 \mu \mathrm{g}$ total RNA, extracted from heart, soleus, diaphragm, rhomboideus, longissimus dorsi and liver, using methods similar to those described previously (Dauncey et al. 1994). Samples were hybridised with a small molar excess of the radiolabelled TR riboprobe, as determined by titration analysis, to ensure linearity of the assay with respect to RNA. After $16 \mathrm{~h}$ hybridisation at $45^{\circ} \mathrm{C}$ excess non-protected RNA was digested with RNase A $(50 \mu \mathrm{g} / \mathrm{ml} \sim 1 \mathrm{U} /$ sample; Sigma) and RNase T1 (300 U/ml 80 U/ sample; Sigma). The protected hybridisation products were purified by extraction in phenol: chloroform:isoamyl alcohol $(25: 24: 1)$ and analysed by polyacrylamide-urea gel electrophoresis, followed by autoradiography. Expression levels of the two TR isoforms were quantified by image analysis, with values being expressed as optical density units. Significance of differences was tested using Student's paired $t$-test.

\section{RESULTS}

\section{Sequences of the porcine TR isoforms}

In addition to several smaller overlapping gene fragments, two complete cDNAs encoding the porcine $\mathrm{TR} \alpha 1$ and $\mathrm{TR} \alpha 2$ receptor variants, and a partial cDNA sequence for TR $\beta 1$ were successfully cloned and sequenced (EMBL Nucleotide Sequence Database Accession Numbers AJ005797, AJ005798 and AJ238614 respectively). Due to the stringent and thorough cloning strategy employed, the authors are certain that the sequences are accurate and that no errors have been introduced as a result of DNA polymerase activity. In total the following were cloned: $1906 \mathrm{bp}$ of the porcine TR $\alpha 1 \mathrm{cDNA}$, corresponding to bases -136 to $1770 ; 1977 \mathrm{bp}$ of the TR $\alpha 2$ cDNA corresponding to bases -136 to 1898; and 611 bases of the TR $\beta 1$, homologous to nucleotides 21 to 631 of the human TR $\beta 1$ coding region (Weinberger et al. 1986). For TRa1, the clone comprised the entire pig TR $\alpha 1 \mathrm{cds}, 136 \mathrm{bp}$ of 5' UTR, and $553 \mathrm{bp}$ of 3' UTR. For TR 2 , the clone comprised the entire pig TR $\alpha 2 \mathrm{cds}, 136 \mathrm{bp}$ of 5' UTR, and $370 \mathrm{bp}$ of $3^{\prime}$ UTR. The TR $\alpha 1$ and TR $\alpha 2$ open reading frames encode proteins of 410 and 506 amino acids (Fig. 2), with predicted average molecular masses of $46 \cdot 8$ and $56 \cdot 3 \mathrm{kDa}$ respectively.

Database searching with these sequences revealed them to be unique, with highest DNA identity $(>95 \%)$ to the appropriate human sequences (Weinberger et al. 1986, Nakai et al. 1988, Laudet et al. 1991). The predicted amino acid sequences of the porcine TR $\alpha$ cDNAs were used to produce multiple sequence alignments with other known $\mathrm{TR} \alpha$ peptide sequences (Fig. 2). A progressive, pair-wise alignment was carried out using the program PileUp (part of Wisconsin Package Version 9.0-UNIX; Genetics Computer Group (GCG) Inc., Madison, Wisconsin, USA), which uses an alignment method similar to that described previously (Higgins \& Sharp 1989). Figure 2a shows the results for alignment of the TRa1 peptides. The human amino acid sequence was most similar to pig, with only one conservative amino acid substitution at position 170 (isoleucine to valine), followed by sheep (Ovis aries) (Tucker \& Polk 1996), rat (Rattus norvegicus) (Thompson et al. 1987), mouse (Mus musculus) (Masuda et al. 1990), chicken (Gallus gallus) (Sap et al. 1986), Muscovy duck (Cairina moschata) (Lachuer et al. 1996), bull frog (Rana catesbeiana) (Schneider et al. 1993), African clawed frog (Xenopus laevis) (Brooks et al. 1989), Japanese flounder (Paralichthys olivaceus) (Yamano et al. 1994) and zebrafish (Danio rerio) (Essner et al. 1997). The TR $\alpha 2$ cDNA has been cloned completely in only two other species, human and rat (Lazar et al. 1988), and partially in the mouse (Prost et al. 1988); the results of alignment of these sequences with the pig are shown in Fig. $2 b$. The human TR 22 peptide was most homologous to pig, followed by rat and mouse. All three complete TR 22 peptide sequences showed a high level of variation in the $\mathrm{C}$-terminal region of the $\mathrm{LBD}$, 


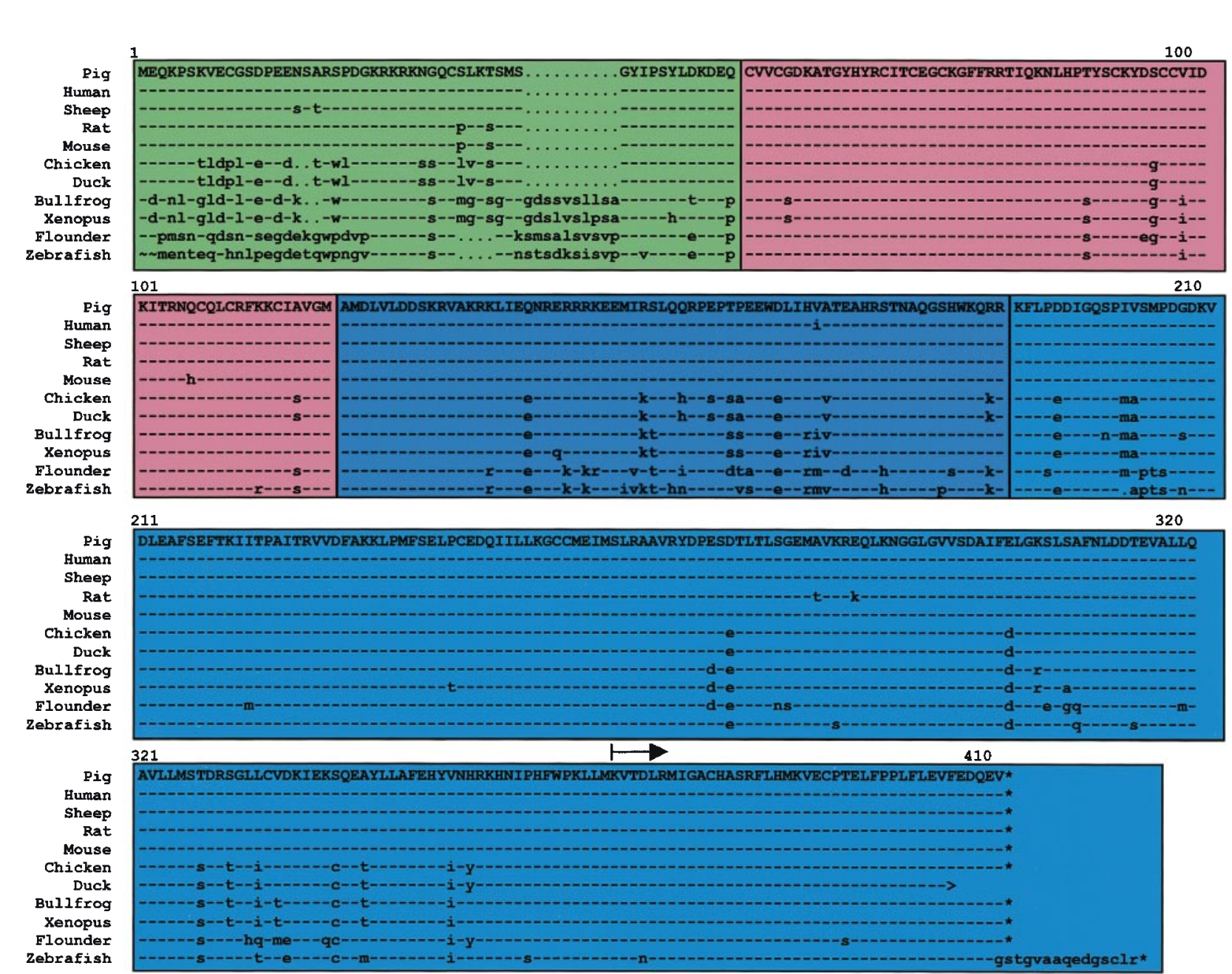

(a). $T R \alpha 1$

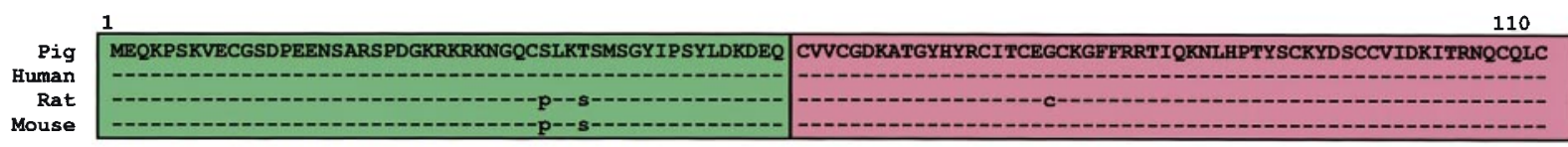

111

220

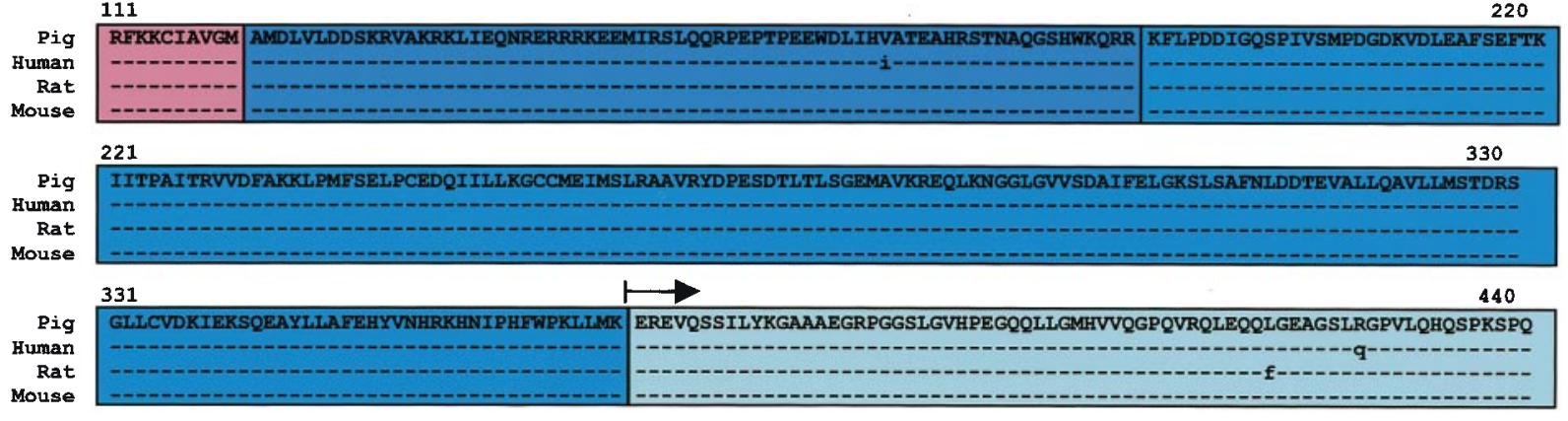

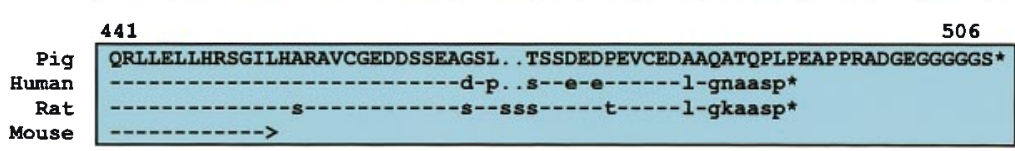

(b). $T R \alpha 2$ 
resulting in the pig TR $\alpha 2$ peptide being longer (506 amino acids) than that of human (490 amino acids) and rat (492 amino acids). The lower level of homology in the last 30 amino acids of the porcine $\mathrm{TR} \alpha 2$ sequence, compared with human and rat, might possibly suggest that this isoform is another as yet uncharacterised splicing variant. However, with the lack of sequence data available for TR $\alpha 2$ in other species, this conclusion cannot be substantiated. A much more likely conclusion, based on the extremely high level of identity over the entire length of this sequence and the human and rat TR $\alpha 2$ cDNAs, is that it is indeed TR 22 .

Alignment of the TR $\alpha 1$ peptide sequences allowed us to produce a phylogenetic tree showing relationships between the TR 1 protein in different species (Fig. 3). A distance matrix was calculated and corrected for multiple substitutions at a single site using the Jukes-Cantor method (using the GCG 9 programme, Distance). The phylogenetic tree was reconstructed from this distance matrix using the unweighted pair group method and arithmetic averages (UPGMA; using the GCG 9 programme, Grow Tree). The tree clearly shows a particularly high level of homology between human and porcine TR $\alpha 1$ isoforms.

\section{Characterisation of porcine TR mRNAs}

Northern blotting of RNA prepared from several tissues demonstrated the presence of three TR $\alpha$ mRNA species and four TR $\beta$ mRNA species (Fig. 4). The TR $\alpha 1$ specific probe hybridised to $5 \cdot 3$ and $7 \cdot 4 \mathrm{~kb}$ transcripts, while the TR $\alpha 2$-specific probe hybridised to 2.5 and $7.4 \mathrm{~kb}$ transcripts. Therefore, the $5.3 \mathrm{~kb}$ transcript encodes the $\alpha 1$ variant, and the $2.5 \mathrm{~kb}$ transcript the non-TH binding $\alpha 2$ variant. The $7 \cdot 4 \mathrm{~kb}$ transcript was detected by both probes, suggesting that it contains sequences encoding the unique 3 ' ends of TR $\alpha 1$ and 'TR $\alpha 2$ mRNAs. The $\operatorname{TR} \beta$ Northern probe hybridised to a large mRNA species of $7.4 \mathrm{~kb}$; several smaller transcripts of 3.9 , 2.5 and $1.5 \mathrm{~kb}$ were also expressed, but at a much lower level than the $7 \cdot 4 \mathrm{~kb}$ transcript. The TR $\beta$ mRNA transcripts appeared to be expressed at a much lower level than the $\mathrm{TR} \alpha$ transcripts, since autoradiography was for 10 days with the TR $\beta$ probe but only 3 days with the TR $\alpha$ probes.
Figure 4 shows that diaphragm and rhomboideus expressed the highest level of the TR $\alpha 1$ transcript, while heart and cerebrum expressed the highest level of $\mathrm{TR} \alpha 2$; the $7.4 \mathrm{~kb} \mathrm{TR} \alpha$ transcript was expressed at the greatest level in heart. All three TR $\alpha$ transcripts were expressed at their lowest level in liver, and were also relatively low in the thyroid gland. Expression of the $7 \cdot 4 \mathrm{~kb}$ TR $\beta$ transcript was highest in heart, followed by diaphragm, rhomboideus, liver and brain. Soleus and longissimus dorsi had low expression levels of TR $\beta$, and the transcript was barely detectable in thyroid gland.

\section{Tissue-specific expression of the porcine TRa and TRß isoforms}

By contrast with Northern blotting, RNase protection gave a considerably more detailed expression analysis of all four TR isoforms. The TR $\alpha$ riboprobe had been designed to detect the $\alpha 1$ and $\alpha 2$ isoforms simultaneously (Fig. 1), giving protected hybridisation products of 218 and $153 \mathrm{bp}$ respectively. Similarly, the TR $\beta$ riboprobe gave protected hybridisation products of 230 and 154 bp for $\beta 1$ and $\beta 2$ respectively. The proportions of $\left[\alpha^{32} \mathrm{P}\right] \mathrm{UTP}$ incorporated into each hybridisation product were calculated and these ratios were used to correct the optical density values. In this way, the relative levels of TR isoform expression could be determined both between and within individual tissues.

For all tissues, expression of the $\mathrm{TR} \alpha$ isoforms was considerably greater than that of the TR $\beta$ isoforms. RNase protections using the TR $\alpha$ riboprobe required overnight exposure to $\mathrm{X}$-ray film, whereas those with the TR $\beta$ riboprobe required exposure for 3 to 5 days. This difference in expression of $\mathrm{TR} \alpha$ compared with $\mathrm{TR} \beta$ is illustrated in Fig. 5 for heart and longissimus dorsi.

Major differences were observed with respect to the relative abundance of the four TR isoforms both between and within tissues (Figs 6 and 7). Expression of TRa1 was similar in all muscles, whereas TR $\alpha 2$ showed a very much more variable pattern of expression (Fig. 6). The expression of TR $\alpha 2$ was extremely high in heart, and more than double that in soleus, diaphragm, and rhomboideus. By contrast, TR 2 expression in longissimus dorsi was less than half that in the other skeletal muscles,

FIGURE 2. Alignment of porcine (a) TR $\alpha 1$ and (b) TR $\alpha 2$ amino acid sequences with other published TR 1 and TR $\alpha 2$ sequences, respectively. Computer-aided multiple sequence alignment (PileUp, GCG 9) shows high level of conservation between the known $\mathrm{TR} \alpha 1$ and $\mathrm{TR} \alpha 2$ isoforms. Numbers above sequences represent porcine amino acid residues. Colours represent the different domains as described in Figure 1. Highest levels of homology were seen in the DNA binding domain (red), followed by the ligand binding domain (shades of blue), with lowest homology in the amino-terminal domain (green). Arrow indicates the position where TR $\alpha 1$ and $\mathrm{TR} \alpha 2$ sequences diverge. 


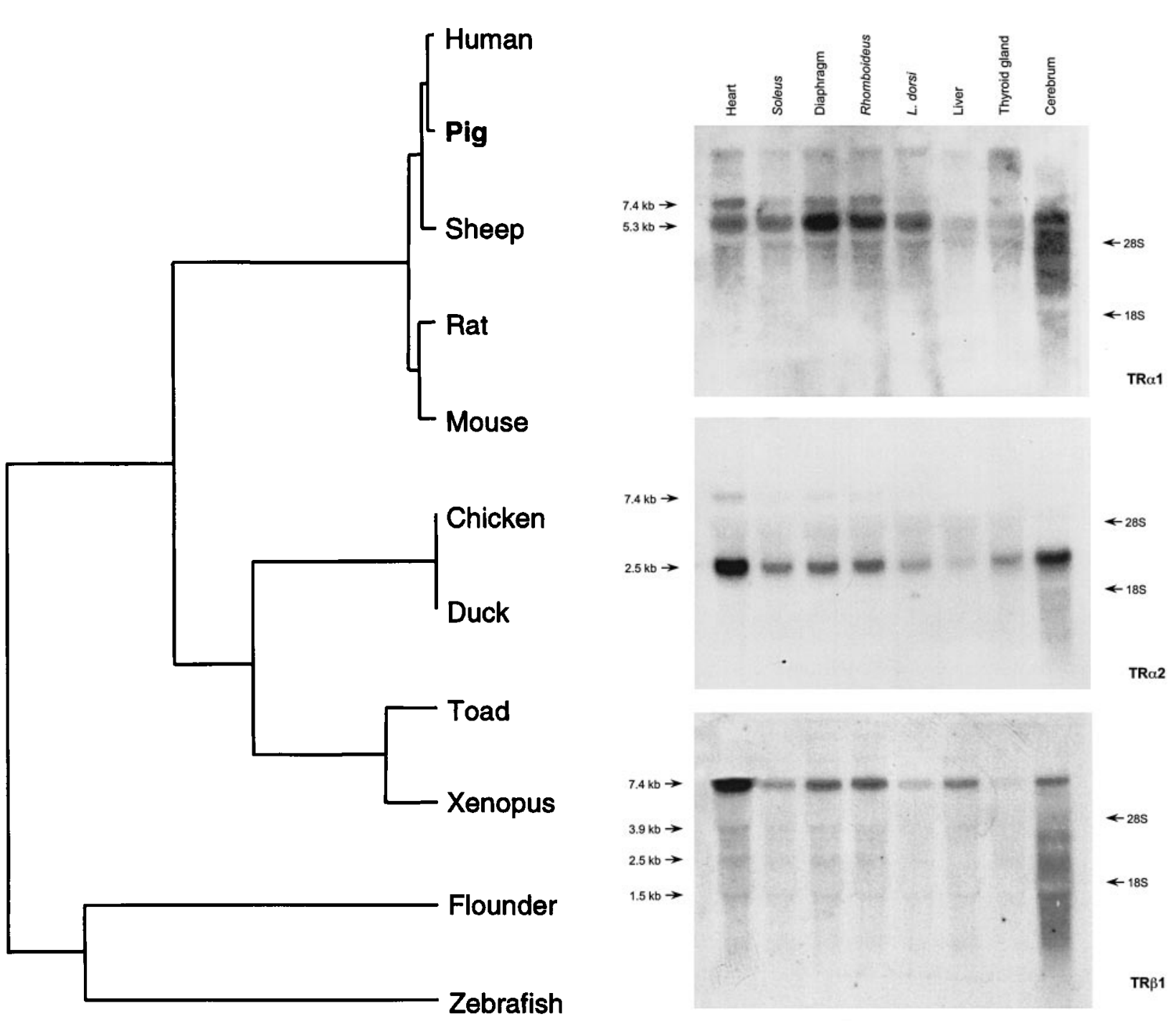

FIgURE 3. Phylogenetic tree of known TR 1 homologues. Note the high level of homology between human and porcine TR $\alpha 1$ isoforms. The tree was inferred from amino acid translations using distance methods. A distance matrix was computed (Jukes-Cantor distance correction; Distance, GCG 9) and then the tree was computed using the unweighted pair group method with an arithmetic mean (UPGMA; GrowTree, GCG 9).

and less than one fifth of that in heart. Expression of the two TR $\alpha$ isoforms was lowest in liver.

Particularly striking were the tissue-specific differences in relative levels of TR $\alpha$ isoforms within each muscle. In heart, the relative level of $\alpha 2$ was more than twice that of $\alpha 1 \quad(P<0 \cdot 01)$, whereas in soleus, diaphragm and rhomboideus there were no significant differences between the two isoforms. However, longissimus dorsi and liver showed the

FIGURE 4. Northern blot analysis of the porcine TR isoforms. Total RNAs $(20 \mu \mathrm{g})$ isolated from tissues from a 7 -week-old pig were hybridised with ${ }^{32} \mathrm{P}$-labelled cDNA probes as described in Fig. 1. Top panel shows the blot hybridised with the TRa1-specific probe; middle panel shows hybridisation with the TR $\alpha 2$ specific probe; bottom panel shows hybridisation with the TR $\beta$-specific probe. Values on the right indicate the position of the $18 \mathrm{~S}(1.6 \mathrm{~kb})$ and $28 \mathrm{~S}(4 \mathrm{~kb})$ ribosomal RNAs; those on the left, the size of the detected transcripts. The TR $\alpha$ transcripts were expressed at a much higher level than the TR $\beta$ transcripts; autoradiography was for 3 days with the TR $\alpha$ probes but for 10 days with the TR $\beta$ probe.

opposite pattern of expression, with levels of $\alpha 1$ being twice as great as $\alpha 2(P<0 \cdot 001)$.

Although TR $\beta$ isoform expression was considerably less than $\mathrm{TR} \alpha$ isoform expression, a 

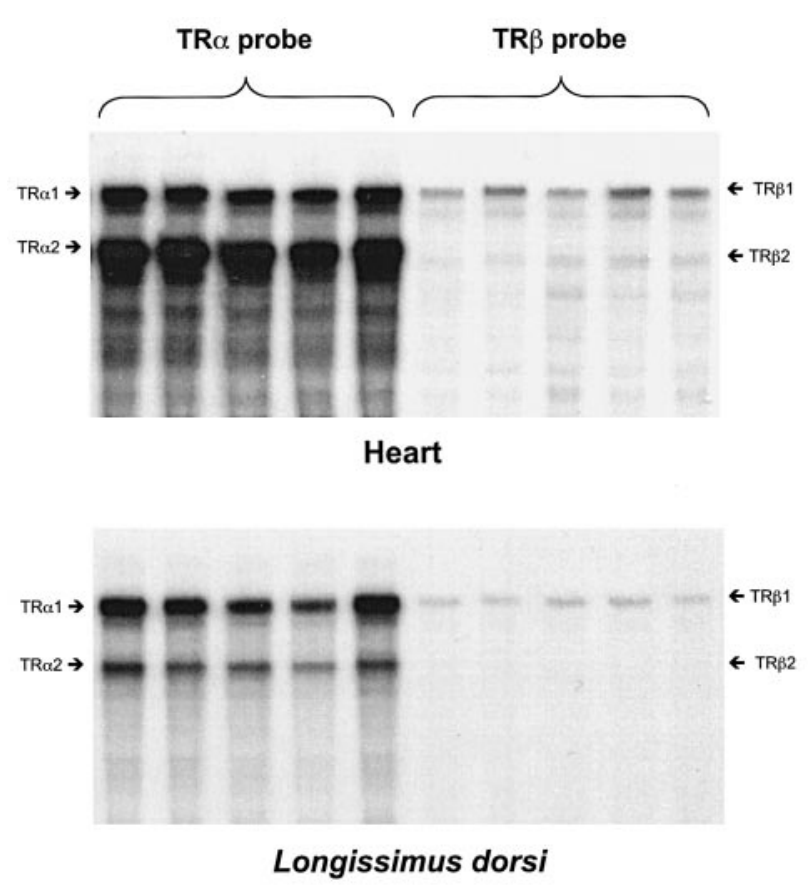

FIgURE 5. Comparison of TR $\alpha$ and TR $\beta$ expression in heart and longissimus dorsi. RNase protection was undertaken with both the TR riboprobes in tissues from five 7 -week-old pigs that had been fed a controlled amount of food and kept at $26{ }^{\circ} \mathrm{C}$ for the previous 4 weeks. Autoradiographs demonstrate the high level of TR $\alpha$ mRNA expression compared with the very much lower level of TR $\beta$ mRNA expression in both tissues; autoradiography was for $48 \mathrm{~h}$ for both assays.

tissue-specific pattern of distribution was again seen for these isoforms (Fig. 7). At 7 weeks postnatally the levels of TR $\beta 1 \mathrm{mRNA}$ were highest in heart, intermediate in soleus, diaphragm, rhomboideus and liver, and lowest in longissimus dorsi. The tissuespecific pattern of TR $\beta 2$ expression was similar to that of TR $\beta 1$, although for all tissues examined expression of TR $\beta 2$ was significantly lower than that of TR $\beta 1$.

\section{DISCUSSION}

We have successfully cloned and characterised for the first time the cDNAs encoding the porcine TR isoforms. Multiple sequence alignment and phylogenetic analysis demonstrated that the porcine TR sequences were most similar to those of human, supporting the use of the young pig as a particularly good biological model for the human infant. Detailed expression analysis using RNase protection demonstrated distinct and previously unreported patterns of TR isoform expression in a range of functionally distinct muscles.

The sequences of the TR $\alpha$ variants showed very high homology in a group of divergent species ranging from fish to man. The highest level of homology was seen in the DNA binding domain (DBD), followed by the ligand binding domain (LBD), then the hinge domain. The lowest level of homology was seen in the N-terminal A/B domain. This is consistent with the modular organisation of the majority of nuclear receptors, in which DBDs and LBDs are conserved in all family members with only a few exceptions (Laudet 1997). The fact that these receptors have been so highly conserved during evolution clearly indicates the important functional roles of both the TR $\alpha$ isoforms. Gene knockout studies on TR $\alpha$ in mice demonstrate some of these functions during postnatal development (Hsu \& Brent 1998). Abrogation of TR $\alpha 1$ and TR $\alpha 2$ results in severe developmental problems, including growth arrest, incomplete maturation of the small intestine and especially the smooth muscle layers, impaired bone development, hypothyroidism and death within 5 weeks of birth (Fraichard et al. 1997).

Use of TR $\alpha$ isoform-specific probes showed that in the pig, mRNA transcripts of 5.3 and $2.5 \mathrm{~kb}$ encode TR $\alpha 1$ and TR $\alpha 2$ respectively. The human TR $\alpha 1$ protein is translated from mRNA of $5.0 \mathrm{~kb}$ which contains a lengthy $3^{\prime}$ UTR, a feature common among nuclear receptor genes; the TR $\alpha 2$ protein is translated from mRNA of $2.7 \mathrm{~kb}$. These similarities in size between the two species suggest that the genomic organisation of the porcine c-erbA- $\alpha$ gene is similar to that of human, in which the TR $\alpha$ gene is split into 10 exons distributed along $27 \mathrm{~kb}$ of chromosome 17 (Laudet et al. 1991). In our study, both probes also revealed the presence of a third transcript of $7.4 \mathrm{~kb}$, the abundance of which followed an expression pattern similar to that of the $\mathrm{TR} \alpha 2$ transcript: highest level in heart, lowest in liver. The presence of a similarly large transcript has been reported in mouse $(6 \cdot 4 \mathrm{~kb})$ (Wood et al. 1991) and rat (6.6 kb) (Murray et al. 1988), and may represent precursor mRNAs from which the smaller transcripts are generated.

The pattern of TR $\beta$ mRNA transcript expression was markedly different from that of TR $\alpha$. Use of a probe designed to detect transcripts encoding both $\operatorname{TR} \beta$ isoforms revealed that this gene is expressed in several tissues as an abundant $7 \cdot 4 \mathrm{~kb}$ mRNA and several smaller, less abundant transcripts of $3 \cdot 9,2 \cdot 5$ and $1.5 \mathrm{~kb}$. As with $\mathrm{TR} \alpha$, this pattern of mRNA expression is very similar to the human: an abundant transcript of $10 \mathrm{~kb}$ and several smaller, less abundant transcripts of 5, 3 and $2 \mathrm{~kb}$ have been 

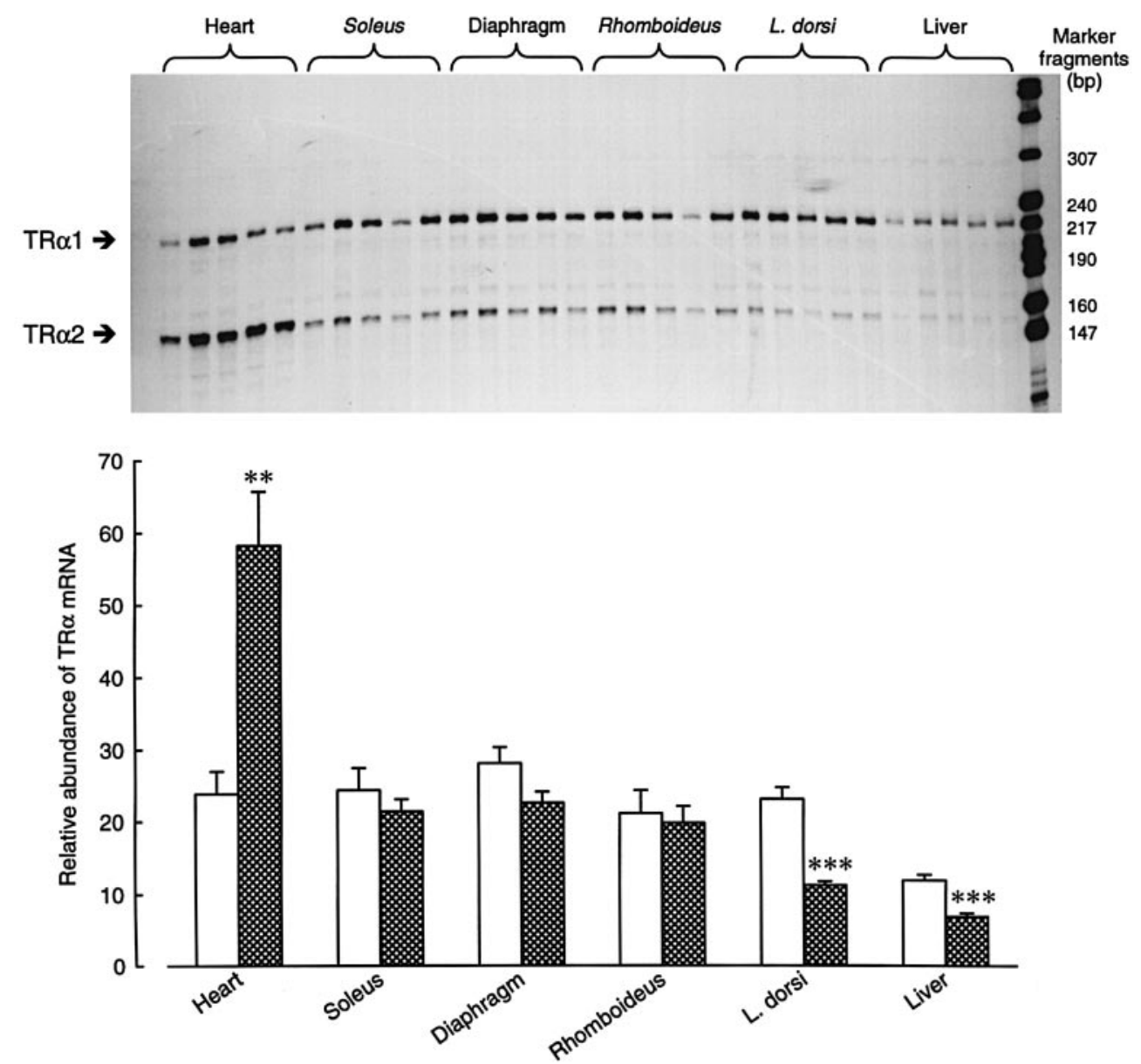

FIGURE 6. TR $\alpha 1$ and TR $\alpha 2$ expression study. RNase protection was undertaken in tissues from five 7-week-old pigs that had been fed a controlled amount of food and kept at a temperature close to thermal neutrality $\left(26^{\circ} \mathrm{C}\right)$ for the previous 4 weeks. Protected bands (top) were quantified by image analysis and relative levels of TR $\alpha 1$ (open bars) and TR $\alpha 2$ (hatched bars) mRNAs are shown in the histogram (bottom); values are means +s.E.M. Significance of difference between TR $\alpha 1$ and TR $\alpha 2$ within each tissue: *** $P<0 \cdot 01$, *** $P<0 \cdot 001$. Autoradiography was for 1 day.

reported (Sakurai et al. 1989). It was suggested that the smaller transcripts could be degradation products of the $10 \mathrm{~kb}$ mRNA. However, the results of the current study would suggest that they represent alternative TR $\beta$ mRNAs. Since the probe detected both isoforms it is not possible to say whether these transcripts represent the different isoforms.

An indication of the distribution of TR isoforms in various tissues was first obtained by Northern blotting, but this did not provide quantitative data nor did it allow assessment of relative distribution of the isoforms within a tissue. This problem was overcome by the use of rigorously optimised RNase protection analysis (White \& Dauncey 1998). Particularly striking was the finding that cardiac tissue expresses a very high level of the non-TH binding $\alpha 2$ variant compared with the level of TRa1, whereas in longissimus dorsi the opposite pattern of distribution occurs, with TR $\alpha 1$ being the predominant isoform. The expression of TR $\beta 1$ was greater than TR $\beta 2$ in all tissues and relative levels of each isoform were muscle specific. However, the functional significance of these differences in TR $\beta$ is unclear because TR $\beta$ expression was considerably lower than that of TR $\alpha$, suggesting that in muscle these isoforms may maintain a level of basal responsiveness to $\mathrm{TH}$. The high sensitivity of the 

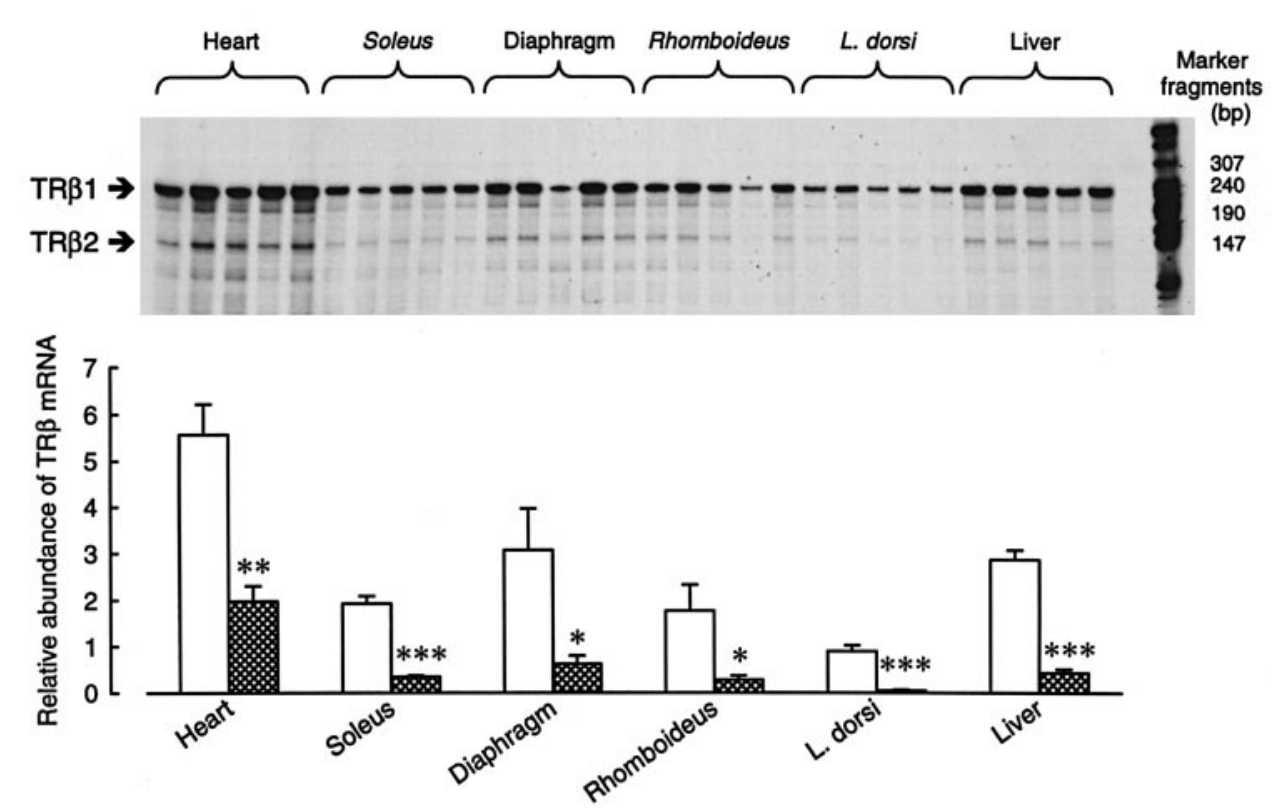

FIGURE 7. TR $\beta 1$ and TR $\beta 2$ expression study. RNase protection was undertaken in tissues from five 7 -week-old pigs that had been fed a controlled amount of food and kept at a temperature close to thermal neutrality $\left(26^{\circ} \mathrm{C}\right)$ for the previous 4 weeks. Protected bands (top) were quantified by image analysis and relative levels of TR $\beta 1$ (open bars) and TR $\beta 2$ (hatched bars) mRNAs are shown in the histogram (bottom); values are means +s.E.M. Significance of difference between TR $\beta 1$ and TR $\beta 2$ within each tissue: $* P<0 \cdot 05$, ** $P<0 \cdot 01$, *** $P<0 \cdot 001$. Autoradiography was for 4 days.

RNase protection assay allowed detection and quantification of extremely low levels of TR $\beta 2 \mathrm{mRNA}$ in all the tissues investigated.

The findings on muscle-specific differential expression of TR $\alpha$ isoforms are relevant to our understanding of the acquisition of optimal muscle function. It has been speculated that the differing responses of various skeletal muscles to $\mathrm{TH}$ are due to differences in total TRs, muscles with a higher TR number being more sensitive to the effects of TH (d'Albis \& Butler-Browne 1993). Although the relation between observed differences in TR isoform mRNAs and expression of TR isoform protein remains to be established, our findings suggest that it is the pattern of TR isoform expression, rather than total TRs, that may regulate muscle phenotype. The TR $\alpha 2$ variant cannot actively inhibit transcription (Tagami et al. 1998) but its dominant negative activity will protect the tissue from the action of TH by competing with TR 1 for TRE binding. By this definition, of the muscles examined longissimus dorsi will be the most sensitive and heart the least sensitive to the action of TH. In view of the role of $\mathrm{TH}$ in inducing switching from type I slow MyHC to type II fast MyHC (Izumo et al. 1986), in muscles where TR 1 predominates over TR 22 the majority of myofibres should express fast MyHC. By contrast, in muscles where TR $\alpha 2$ predominates, the majority of myofibres should express mainly slow MyHC. This hypothesis fits closely with the present findings. In 7 -week-old pigs kept under the same conditions as those of the present study, longissimus dorsi contains approximately $90 \%$ fast $\mathrm{MyHC}$, the other skeletal muscles examined have similar proportions of fast and slow MyHC, whereas heart contains only slow MyHC (Harrison et al. 1996a, P White, D Cattaneo and M J Dauncey, unpublished observations). Thus, the potential for rapid movement by longissimus dorsi will be accentuated by its relatively high level of TR 1 , and the maintenance of slow sustained contractility by the heart will be enhanced by its high level of TR $\alpha 2$.

The present results are particularly relevant to our understanding of the roles of THs and TRs in regulating cardiac function postnatally. In mice lacking TR 1 because of a null mutation of the TR $\alpha 1$ locus, an abnormally low heart rate was observed (Wikstrom et al. 1998). The authors could not explain the mechanism involved because none of the well-known TR target genes in the heart such as $\mathrm{Ca}^{2+}$-ATPase, $\mathrm{Na}^{+}, \mathrm{K}^{+}$-ATPase and $\beta$-adrenergic 
receptors were dysregulated. However, cardiac MyHC expression was not investigated. In humans, excessive production of $\mathrm{TH}$ s has a severe impact on cardiac function, with symptoms including increased blood flow and cardiac output (Woeber 1992); the opposite effects occur with TH deficiency. These TH-induced changes in contractility are dependent on the relative amounts of $\alpha-\mathrm{MyHC}$ and $\beta$-MyHC gene products expressed in cardiac tissue (Brent 1994). The products of the two cardiac $\mathrm{MyHC}$ chain genes dimerise to form three $\mathrm{MyHC}$ isoforms: $\alpha / \alpha, \alpha / \beta$ and $\beta / \beta$. Hearts rich in $\alpha$-MyHC have a high intrinsic contractility state, due to the higher ATPase activity of this protein, while a preponderance of $\beta-\mathrm{MyHC}$ is associated with a greater economy of force maintenance. These genes are regulated in an antithetical manner, $\mathrm{T}_{3}$ increases the expression of $\alpha-\mathrm{MyHC}$ while simultaneously decreasing that of $\beta$-MyHC (Haddad et al. 1997), and in euthyroid rats and rabbits the $\alpha / \alpha$ myosin isoform predominates whereas in hypothyroid animals the $\beta / \beta$ isoform predominates. These data in combination with the present results suggest that the balance between relative expression of $\mathrm{TR} \alpha 1$ and $\mathrm{TR} \alpha 2$, and the level of circulating THs, is essential in regulating cardiac $\mathrm{MyHC}$ expression. In the case of TR $\alpha 1$-deficient mice, expression of only the TR $\alpha 2$ variant would lead to a reduction in cardiac $\alpha-\mathrm{MyHC}$ expression, and thus a reduced cardiac output.

In conclusion, our study suggests a role for TR isoforms in the regulation of muscle phenotype, with relative levels of the highly expressed TR $\alpha 1$ and TRa2 controlling $\mathrm{TH}$ action in switching between fast and slow MyHC, and the less abundant TR $\beta$ providing a basal level of $\mathrm{TH}$ responsiveness. Recent studies of myofibre proportions in the soleus muscle of TR knockout mice support this hypothesis (Yu et al. 1999). Abrogation of both $\mathrm{TR} \alpha$ isoforms resulted in a significant upregulation of type I MyHC, while lack of TR $\beta$ did not alter MyHC composition. Our results also suggest an important role for the ratio TR $\alpha 1$ :TR $\alpha 2$ in development and optimal function of the heart. The possibility that TR $\alpha$ isoforms have specific functions in cardiac and skeletal muscle is supported by recent studies of postnatal development in TR knockout mice, which highlight specific functions for $\operatorname{TR} \alpha$ and $\operatorname{TR} \beta$ in many tissues, and demonstrate only partial functional redundancy between these two families of TR (Gauthier et al. 1999). Future studies should focus on developmental and environmental regulation of the TR genes, and additional factors that are required for optimal TR function. Thus, TRs require heterodimerisation with retinoid $\mathrm{X}$ receptor (RXR) for maximal DNA binding affinity (Reginato et al. 1996). A study on the relative levels of the $\alpha, \beta$ and $\gamma$ forms of the RXR family in heart and functionally distinct skeletal muscles would further elucidate the complex regulatory roles of the TR isoforms.

\section{ACKNOWLEDGEMENTS}

We thank Dr J Li for excellent advice and critical reading of the manuscript, $\mathrm{Mr} \mathrm{KA}$ Burton for invaluable technical assistance and $\mathrm{Mr} \mathrm{J}$ Coadwell for expert advice on sequence analysis and bioinformatics. PW was in receipt of a Medical Research Council Postgraduate Studentship. The Babraham Institute is supported by the Biotechnology and Biological Sciences Research Council.

\section{REFERENCES}

d'Albis A \& Butler-Browne G 1993 The hormonal control of myosin isoform expression in skeletal muscle of mammals: a review. Basic and Applied Myology 3 7-16.

Bakker O, Razaki H, de Jong J, Ris-Stalpers C \& Wiersinga WM 1998 Expression of the $\alpha 1, \alpha 2$, and $\beta 1$ T3-receptor mRNAs in the fasted rat measured using competitive PCR Biochemical and Biophysical Research Communications 242 492-496.

Barnes WM 1994 PCR amplification of up to 35-kb DNA with high fidelity and high yield from lambda bacteriophage templates. Proceedings of the National Academy of Sciences of the USA $912216-2220$.

Brent GA 1994 The molecular basis of thyroid hormone action. New England Fournal of Medicine 331 847-853.

Brooks AR, Sweeney G \& Old RW 1989 Structure and functional expression of a cloned Xenopus thyroid hormone receptor. Nucleic Acids Research 17 9395-9405.

Chin WW \& Yen PM 1997 Molecular mechanisms of nuclear thyroid hormone action. In Diseases of the Thyroid, pp 1-15. Ed LE Braverman. Totowa, New Jersey: Humana Press.

Chomczynski P \& Sacchi N 1987 Single-step method of RNA isolation by acid guanidinium thiocyanate-phenol-chloroform extraction. Analytical Biochemistry 162 156-159.

Dauncey MJ 1990 Thyroid hormones and thermogenesis. Proceedings of the Nutrition Society 49 203-215.

Dauncey MJ \& Harrison AP 1996 Developmental regulation of cation pumps in skeletal and cardiac muscle. Acta Physiologica Scandinavica 156 313-323.

Dauncey MJ, Burton KA, White P, Harrison AP, Gilmour RS, Duchamp C \& Cattaneo D 1994 Nutritional regulation of growth hormone receptor gene expression. FASEB fournal 8 81-88.

Davis PJ \& Davis FB 1997 Nongenomic actions of thyroid hormone. In Diseases of the Thyroid, pp 17-34. Ed LE Braverman. Totowa, New Jersey: Humana Press.

Duchamp C, Burton KA, Herpin P \& Dauncey MJ 1994 Perinatal ontogeny of porcine nuclear thyroid hormone receptors and its modulation by thyroid status. American Fournal of Physiology 267 E687-E693.

Essner JJ, Breuer JJ, Essner RD, Fahrenkrug SC \& Hackett PB Jr 1997 The zebrafish thyroid hormone receptor $\alpha 1$ is 
expressed during early embryogenesis and can function in transcriptional repression. Differentiation 62 107-117.

Fraichard A, Chassande O, Plateroti M, Roux JP, Trouillas J, Dehay C, Legrand C, Gauthier K, Kedinger M, Malaval L, Rousset B \& Samarut J 1997 The T3R $\alpha$ gene encoding a thyroid hormone receptor is essential for post-natal development and thyroid hormone production. $E M B O$ Fournal 16 4412-4420.

Gauthier K, Chassande O, Plateroti M, Roux JP, Legrand C, Pain B, Rousset B, Weiss R, Trouillas J \& Samarut J 1999 Different functions for the thyroid hormone receptors $\mathrm{TR} \alpha$ and TR $\beta$ in the control of thyroid hormone production and post-natal development. EMBO Fournal 18 623-631.

Green S \& Chambon P 1986 A superfamily of potentially oncogenic hormone receptors. Nature 324 615-617.

Haddad F, Bodell PW, McCue SA \& Baldwin KM 1997 Effects of diabetes on rodent cardiac thyroid hormone receptor and isomyosin expression. American fournal of Physiology 272 E856-E863.

Harrison AP, Rowlerson AM \& Dauncey MJ $1996 a$ Selective regulation of myofiber differentiation by energy status during postnatal development. American Fournal of Physiology 270 R667-R674.

Harrison AP, Tivey DR, Clausen T, Duchamp C \& Dauncey MJ $1996 b$ Role of thyroid hormones in early postnatal development of skeletal muscle and its implications for undernutrition. British Fournal of Nutrition 76 841-855.

Harrison AP, Latorre R \& Dauncey MJ 1997 Postnatal development and differentiation of myofibres in functionally diverse porcine skeletal muscles. Reproduction, Fertility and Development 9 731-740.

Herpin P, Berthon D, Duchamp C, Dauncey MJ \& Le Dividich J 1996 Effect of thyroid status in the perinatal period on oxidative capacities and mitochondrial respiration in porcine liver and skeletal muscle. Reproduction, Fertility and Development 8 147-155.

Higgins DG \& Sharp PM 1989 Fast and sensitive multiple sequence alignments on a microcomputer. Computer Applications in the Biosciences 5 151-153.

Hsu JH \& Brent GA 1998 Thyroid hormone receptor gene knockouts. Trends in Endocrinology and Metabolism 9 103-112.

Izumo S, Nadal-Ginard B \& Mahdavi V 1986 All members of the MHC multigene family respond to thyroid hormone in a highly tissue-specific manner. Science 231 597-600.

Kotewicz ML, Sampson CM, D'Alessio JM \& Gerard GF 1988 Isolation of cloned Moloney murine leukemia virus reverse transcriptase lacking ribonuclease $\mathrm{H}$ activity. Nucleic Acids Research 16 265-277.

Lachuer J, Ronfort C, Duchamp C, Cohen-Adad F, Barges S, Faraut P, Quivet L, Legras C, Verdier G \& Barré H 1996 Characterization of a cDNA encoding an $\alpha$ thyroid hormone receptor in Muscovy duckling. Poultry Science 75 1531-1535.

Laudet V 1997 Evolution of the nuclear receptor superfamily: early diversification from an ancestral orphan receptor. Fournal of Molecular Endocrinology 19 207-226.

Laudet V, Begue A, Henry-Duthoit C, Joubel A, Martin P, Stehelin D \& Saule S 1991 Genomic organization of the human thyroid hormone receptor $\alpha$ (c-erbA-1) gene. Nucleic Acids Research 19 1105-1112.

Lazar MA 1993 Thyroid hormone receptors: multiple forms, multiple possibilities. Endocrine Reviews 14 184-193.

Lazar MA, Hodin RA, Darling DS \& Chin WW 1988 Identification of a rat c-erbA- $\alpha$ related protein which binds deoxyribonucleic acid but does not bind thyroid hormone. Molecular Endocrinology 2 893-901.

Masuda M, Yasuhara S, Yamashita M, Shibuya M \& Odaka T 1990 Nucleotide sequence of the murine thyroid hormone receptor ( $\alpha 1)$ cDNA. Nucleic Acids Research 183055.
Melton DA, Krieg PA, Rebagliati MR, Maniatis T, Zinn K \& Green MR 1984 Efficient in vitro synthesis of biologically active RNA and RNA hybridization probes from plasmids containing a bacteriophage SP6 promoter. Nucleic Acids Research 12 7035-7056.

Morovat A \& Dauncey MJ 1995 Regulation of porcine skeletal muscle nuclear 3,5,3'-tri-iodothyronine receptor binding capacity by thyroid hormones: modification by energy balance. Fournal of Endocrinology 144 233-242.

Morovat A \& Dauncey MJ 1998 Effects of thyroid status on insulin-like growth factor-I, growth hormone and insulin are modified by food intake. European Fournal of Endocrinology 138 95-103.

Munoz A \& Bernal J 1997 Biological activities of thyroid hormone receptors. European Fournal of Endocrinology 137 433-445.

Murray MB, Zilz ND, McCreary NL, MacDonald MJ \& Towle HC 1988 Isolation and characterization of rat cDNA clones for two distinct thyroid hormone receptors. Fournal of Biological Chemistry 263 12770-12777.

Muscat GE, Downes M \& Dowhan DH 1995 Regulation of vertebrate muscle differentiation by thyroid hormone: the role of the myoD gene family. BioEssays 17 211-218.

Nakai A, Seino S, Sakurai A, Szilak I, Bell GI \& DeGroot LJ 1988 Characterization of a thyroid hormone receptor expressed in human kidney and other tissues. Proceedings of the National Academy of Sciences of the USA 85 27812785 .

Oppenheimer JH, Schwartz HL, Mariash CN, Kinlaw WB, Wong NC \& Freake HC 1987 Advances in our understanding of thyroid hormone action at the cellular level. Endocrine Reviews 8 288-308.

Prost E, Koenig RJ, Moore DD, Larsen PR \& Whalen RG 1988 Multiple sequences encoding potential thyroid hormone receptors isolated from mouse skeletal muscle cDNA libraries. Nucleic Acids Research 166248.

Reginato MJ, Zhang J \& Lazar MA 1996 DNA-independent and DNA-dependent mechanisms regulate the differential heterodimerization of the isoforms of the thyroid hormone receptor with retinoid X receptor. Fournal of Biological Chemistry 271 28199-28205.

Sakurai A, Nakai A \& DeGroot LJ 1989 Expression of three forms of thyroid hormone receptor in human tissues. Molecular Endocrinology 3 392-399.

Sap J, Munoz A, Damm K, Goldberg Y, Ghysdael J, Leutz A, Beug H \& Vennstrom B 1986 The c-erb-A protein is a high-affinity receptor for thyroid hormone. Nature 324 635-640.

Schneider MJ, Davey JC \& Galton VA 1993 Rana catesbeiana tadpole red blood cells express an $\alpha$, but not a $\beta$, c-erbA gene. Endocrinology 133 2488-2495.

Tagami T, Kopp P, Johnson W, Arseven OK \& Jameson JL 1998 The thyroid hormone receptor variant $\alpha 2$ is a weak antagonist because it is deficient in interactions with nuclear receptor corepressors. Endocrinology 139 2535-2544.

Thompson CC, Weinberger C, Lebo R \& Evans RM 1987 Identification of a novel thyroid hormone receptor expressed in the mammalian central nervous system. Science 237 $1610-1614$.

Tucker M \& Polk D 1996 Cloning of the $\alpha$ and $\beta$ ovine thyroid hormone receptor cDNAs. Thyroid 6 237-243.

Weinberger C, Thompson CC, Ong ES, Lebo R, Gruol DJ \& Evans RM 1986 The c-erb-A gene encodes a thyroid hormone receptor. Nature 324 641-646.

White P \& Dauncey MJ 1998 An enhanced method for RNase protection assays using SeeDNA Co-precipitant. (Full version on www.apbiotech.com/publications/lsn-1-16/). Life Science News 123. 
Wikstrom L, Johansson C, Salto C, Barlow C, Campos Barros A, Baas F, Forrest D, Thoren P \& Vennstrom B 1998 Abnormal heart rate and body temperature in mice lacking thyroid hormone receptor $\alpha 1$. EMBO fournal 17 455-461.

Woeber KA 1992 Thyrotoxicosis and the heart. New England Fournal of Medicine 327 94-98.

Wood WM, Ocran KW, Gordon DF \& Ridgway EC 1991 Isolation and characterization of mouse complementary DNAs encoding $\alpha$ and $\beta$ thyroid hormone receptors from thyrotrope cells: the mouse pituitary-specific $\beta 2$ isoform differs at the amino terminus from the corresponding species from rat pituitary tumor cells. Molecular Endocrinology $\mathbf{5}$ 1049-1061.

Yamano K, Araki K, Sekikawa K \& Inui Y 1994 Cloning of thyroid hormone receptor genes expressed in metamorphosing flounder. Developmental Genetics 15 378-382.

Yang YZ, Burgos-Trinidad M, Wu Y \& Koenig RJ 1996 Thyroid hormone receptor variant $\alpha 2$. Role of the ninth heptad in DNA binding, heterodimerization with retinoid $\mathrm{X}$ receptors, and dominant negative activity. Fournal of Biological Chemistry 271 28235-28242.

Yen PM \& Chin WW 1994 Molecular mechanisms of dominant negative activity by nuclear hormone receptors. Molecular Endocrinology 8 1450-1454.

Yu F, Pircher P, Gothe S, Vennstrom B \& Larsson L 1999 Effects of disruption of thyroid hormone receptor gene on the expression of myosin isoform composition of mouse skeletal muscles. FASEB fournal 13 A415.

REVISED MANUSCRIPT RECEIVED 26 May 1999 